\title{
Railway Development
}

Impacts on Urban Dynamics

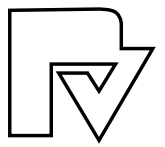


Frank Bruinsma $\cdot$ Eric Pels

Hugo Priemus · Piet Rietveld

Bert van Wee

Editors

\section{Railway Development}

\section{Impacts on Urban Dynamics}

Physica-Verlag

A Springer Company 
Dr. Frank Bruinsma

Dr. Eric Pels

Prof. Dr. Piet Rietveld

Free University of Amsterdam

Department of Spatial Economics

De Boelelaan 1105

1081 HV Amsterdam

The Netherlands

fbruinsma@feweb.vu.nl

apels@feweb.vu.nl

prietveld@feweb.vu.nl
Prof. Dr. Hugo Priemus

Prof. Dr. Bert van Wee

Delft University of Technology

Faculty of Technology,

Policy and Management

P.O. Box 5015

2600 GA Delft

The Netherlands

h.priemus@tbm.tudelft.nl

g.p.vanwee@tbm.tudelft.nl

DOI 10.1007/978-3-7908-1972-4

Library of Congress Control Number: 2007936545

(C) 2008 Physica-Verlag Heidelberg

This work is subject to copyright. All rights are reserved, whether the whole or part of the material is concerned, specifically the rights of translation, reprinting, reuse of illustrations, recitation, broadcasting, reproduction on microfilm or in any other way, and storage in data banks. Duplication of this publication or parts thereof is permitted only under the provisions of the German Copyright Law of September 9, 1965, in its current version, and permission for use must always be obtained from Physica-Verlag. Violations are liable to prosecution under the German Copyright Law.

The use of general descriptive names, registered names, trademarks, etc. in this publication does not imply, even in the absence of a specific statement, that such names are exempt from the relevant protective laws and regulations and therefore free for general use.

Production: LE-TEX Jelonek, Schmidt \& Vöckler GbR, Leipzig

Cover-design: WMX Design GmbH, Heidelberg

Printed on acid-free paper

987654321

springer.com 


\section{Preface}

The revitalisation of railway station areas has been a hot issue in policy making in Europe in recent years. The introduction of two new railway systems - the high speed train and light rail systems - has pushed forward the redevelopment of not only railway stations themselves, but also of their - in many cases deteriorated - direct surroundings. Examples of revitalisation of railway station areas can be found throughout Europe, for example in countries like England (Liverpool), France (Euralille), Germany (Berlin) and the Netherlands (Amsterdam South Axis). The dynamics of revitalisation of railway station areas can best be understood by combining the insights of several disciplines; economics, and spatial sciences being the most important disciplines. This book therefore addresses the subject from a multi-disciplinary perspective.

Railway station area redevelopment projects try to cope with the increased lack of interoperability and interconnectivity between infrastructures and boost the local/regional economy by creating a new high quality multifunctional urban landscape at the same time. At present, the initial outcomes with the transformation of deteriorated railway station areas into modern mixed office, shopping and residential areas stems hopeful, but what are the prospects of those redeveloped areas?

Most of the papers contained in this volume were presented at the special session "Railway stations and urban dynamics" of the $45^{\text {th }}$ conference of the European Regional Science Association (ERSA) held in Amsterdam, the Netherlands during August 2005. There was a special reason for this session during the conference. In the Netherlands several scientific research programs, co-funded by the Dutch government, were directed towards this topic of railway station development and urban dynamics. These programs were Connect-NWO program "Railway stations: interfaces between railway network developments and urban dynamics", Transumo (TRANsition SUstainable MObility) and the BSIK programs "Next generation infrastructures" and "Innovative Land Use". In those programs researchers of several universities participated to assure a multidisciplinary perspective. The conference offered a ideal platform to disseminate the results of the research programs to a broader audience. Moreover, the special session was open for presentations from authors not involved in one of the 
programs. By this the scope of the research extended from a Dutch to a European perspective. Financial support of the programs made it possible to organise the special session and to edit this manuscript. This support is gratefully acknowledged. Sue Davis has assisted in improving the language of non-English speaking authors. We thank her for efficient and conscientious work.

Amsterdam July 2007

Frank Bruinsma

Eric Pels

Hugo Priemus

Piet Rietveld

Bert van Wee 


\section{Contents}

Preface

1 The impact of railway development on urban dynamics

Frank Bruinsma, Eric Pels, Hugo Priemus, Piet Rietveld and Bert van Wee

Part A: Setting the scene

2 Urban dynamics and transport infrastructure:

Towards greater synergy

Hugo Priemus

3 Station areas as nodes and places in urban networks: An analytical tool and alternative development strategies

Luca Bertolini

$4 \quad$ HST stations and urban dynamics: Experiences from four European cities

Peter Pol

5 What makes a city: Urban quality in Euralille, Amsterdam South Axis and Rotterdam Central Jan Jacob Trip

6 New Key Projects for station redevelopment in the Netherlands

Stan Majoor and Dick Schuiling

$7 \quad$ A multidisciplinary approach of railway station development: A case study of 's-Hertogenbosch Gert-Joost Peek and Erik Louw 
Part B: Evaluation studies

$8 \quad$ Ex ante evaluation of railway station development projects: Issues still to be solved Piet Rietveld and Bert van Wee

9 Multicriteria analysis of a high-speed railway station area development project Ron Vreeker

10 Cost-benefit analysis of railway station area development: The case of Amsterdam South Axis Carel Eijgenraam and Ioulia Ossokina

11 Measuring the WTP for shopping facilities around railway stations

Thomas de Graaff and Caroline Rodenburg

Part C: High-speed rail and urban dynamics

12 The impact of high-speed railway developments on office locations: A scenario study approach Jasper Willigers

13 The effect of railway stations on office space rent levels: The implication of HSL South in station Amsterdam South Axis Ghebreegziabiher Debrezion and Jasper Willigers

14 Regional high-speed trains on the Svealand line: Evaluation of effects

Oskar Froïdh and Bo-Lennart Nelldal

15 Rail pricing and the supply of complementary commercial goods

Eric Pels, Erik Louw and Jan Jacob Trip 
Part D: Light rail and urban dynamics

16 Rail system development and urban

transformations: Towards a spatial decision support system

Enrica Papa, Francesca Pagliara and Luca Bertolini

17 Rail-transit and real estate values in a polycentric city: A theoretic simulation approach

Daniel Gat

18 Land use variables in trip generation models: The case of the light rail transit in Tel Aviv Avigail Ferdman, Daniel Shefer and Shlomo Bekhor 